\title{
The contemporary geomorphology of the Letaba River in the Kruger National Park
}

\section{B.P. Moon and G.L. Heritage}

\begin{abstract}
Moon, B.P. and G.L. Heritage. 2001. The contemporary geomorphology of the Letaba River in the Kruger National Park. Koedoe 44(1): 45-55. Pretoria. ISSN 0075-6458.

The Letaba River drains part of Northern Province in north-east South Africa. Its catchment has been modified significantly by human activity which has affected the flow regime; it experiences only ephemeral flows through the Kruger National Park to its confluence with the Olifants River. Although the Letaba is similar to the other rivers in the Kruger National Park in that it displays some bedrock-influenced channel features, increased sediment delivery from the degraded catchment upstream has resulted in extensive alluviation within the channel. Sections of channel flowing over bedrock with no sediment covering are rare, and the river comprises a series of channel types: mixed anastomosing, alluvial braided, mixed pool-rapid and alluvial single thread. Each is characterised by a different combination of morphological units which relate to the degree of alluviation in the channel. These channel types are described in detail and inferences are made concerning their formation and maintenance from field observation and measurement.
\end{abstract}

Key words: channel type, channel change, geomorphology, Letaba River, morphological units.

B.P. Moon, Centre for Water in the Environment, University of the Witwatersrand, 1 Jan Smuts Avenue, Johannesburg, Republic of South Africa (132abm@atlas.wits.ac.za); G.L. Heritage, Department of Geography, Peel Building, University of Salford, Manchester M54WT, United Kingdom (G.L. Heritage@salford.ac.uk).

\section{Introduction}

During the last century the Letaba River in the Kruger National Park has changed from a perennial to an ephemeral river (Steffen Robertson \& Kirsten 1990a). Increased abstraction of water for development, and the construction of dams, have led to a modification of the flow regime and a shift in the balance of catchment control variables (Heritage et al. 1997). The consequent marked geomorphological changes have been documented (Vogt 1992), and a recently-completed five-year project on the rivers of the Kruger National Park has focused on an understanding of those changes (Heritage et al. 1997). Increasing water abstraction and an expansion of agricultural practices are likely to result in further flow reduction and increased sediment inputs to the river (Birkhead et al. 1995) leading to further morphological change.

Recently there has been a marked growth in research into the nature and dynamics of South African river systems (for example, the work of Rowntree \& Wadeson 1996; Wadeson \& Rowntree 1996; Heritage et al. in press; Rountree et al. in press).

In this paper, following an overview of the Letaba catchment, the contemporary geomorphology of the Letaba River is described within the framework of its component channel types. Four different channel types have been recognised: mixed anastomosing, alluvial braided, mixed pool-rapid and alluvial single thread, each reflecting a different combination of morphological units. The nature of change in the different channel types is discussed in relation to reduced flows and increased alluviation over time. 

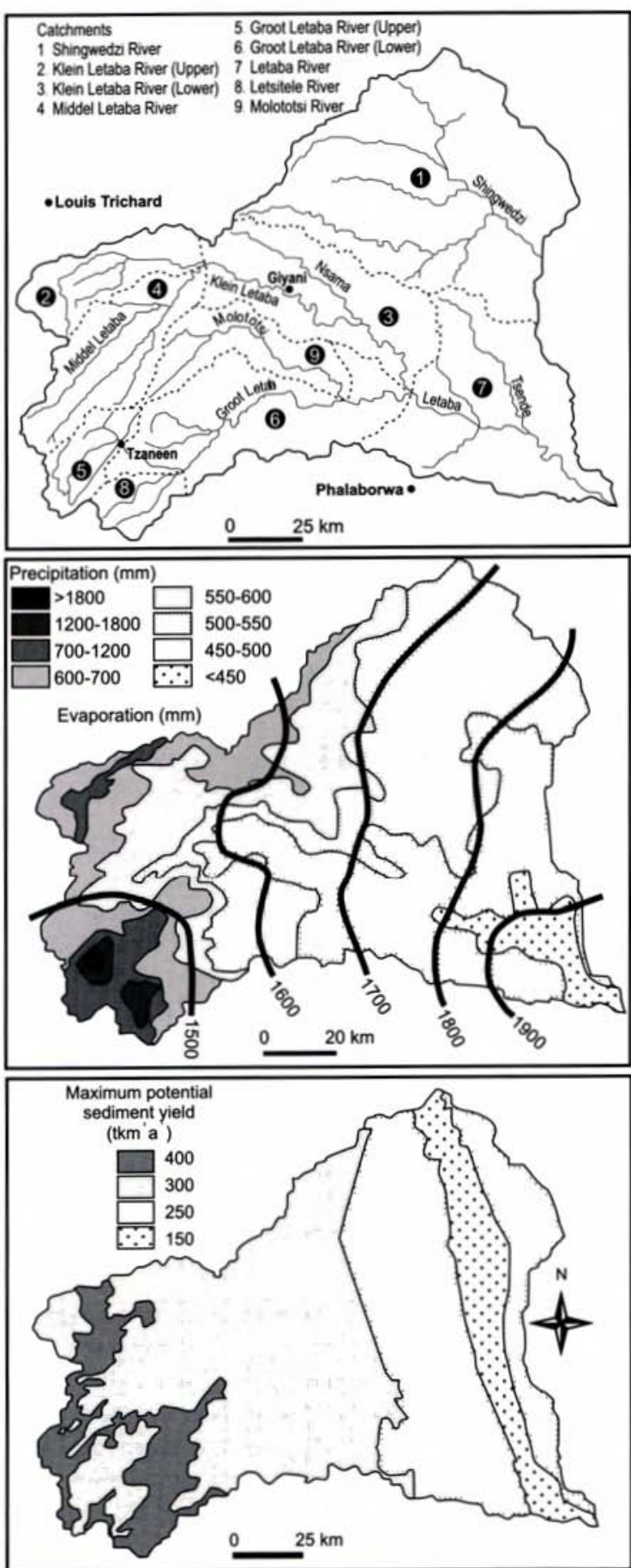

Fig. 1. The Letaba River catchment, Northern Province, South Africa, (a) location, (b) precipitation ( $\mathrm{mm} / \mathrm{a}$ ) and evaporation $(\mathrm{mm} / \mathrm{a})$, (c) sediment production $\left(\mathrm{tkm}^{2} / \mathrm{a}\right)$, (after Steffen Robertson \& Kirsten 1990b).

\section{The Letaba catchment}

The Letaba catchment covers an area of $13400 \mathrm{~km}^{2}$ in the Northern Province of South Africa. In the Lowveld region its major tributaries are the Molotsi and Klein-Letaba rivers, and the Letaba joins the Olifants near the Mozambique border (Fig. 1a). The catchment is classified as semi-arid, receiving between 500 and $1800 \mathrm{~mm}$ of rainfall in the mountainous western parts of the catchment, falling to between $450 \mathrm{~mm}$ and $700 \mathrm{~mm}$ in the east (Fig. 1b). Evaporation is high, ranging from $1400 \mathrm{~mm}$ in the west to $1900 \mathrm{~mm}$ in the east (Fig. 1b). Precipitation is concentrated in the summer months whereas evaporation potential is more evenly distributed (Steffen Robertson \& Kirsten 1990a). Runoff is now seasonal and became ephemeral during the drought of the 1990 s when surface flow in the lower reaches occurred only in response to severe storm events in the catchment. Virgin mean annual runoff has been estimated at 556 million cubic metres per annum $\left(\mathrm{Mm}^{3} / \mathrm{a}\right)$ (Steffen Robertson \& Kirsten 1990a) compared with the present MAR of $323 \mathrm{Mm}^{3} / \mathrm{a}$.

In the upper catchment, outside the park, extensive areas of land are used for forestry and commercial agriculture. Intense subsistence farming and irrigation also occurs along the river where access to water is good (Steffen Robertson \& Kirsten 1990a). Forested areas (47600 ha in 1985) require a water volume of $64 \mathrm{Mm}^{3} / \mathrm{a}$ (Steffen Robertson \& Kirsten 1990a). Irrigation of fruit, vegetables and grain cash crops requires $220 \mathrm{Mm}^{3 / a}$, and domestic and industrial water use amounts to approximately $17 \mathrm{Mm}^{3 / a}$. A further approximately $7 \mathrm{Mm}^{3} / \mathrm{a}$ is exported to urban areas outside the catchment. Potential increase in demand as a result of increasing agricultural, industrial and rural water 

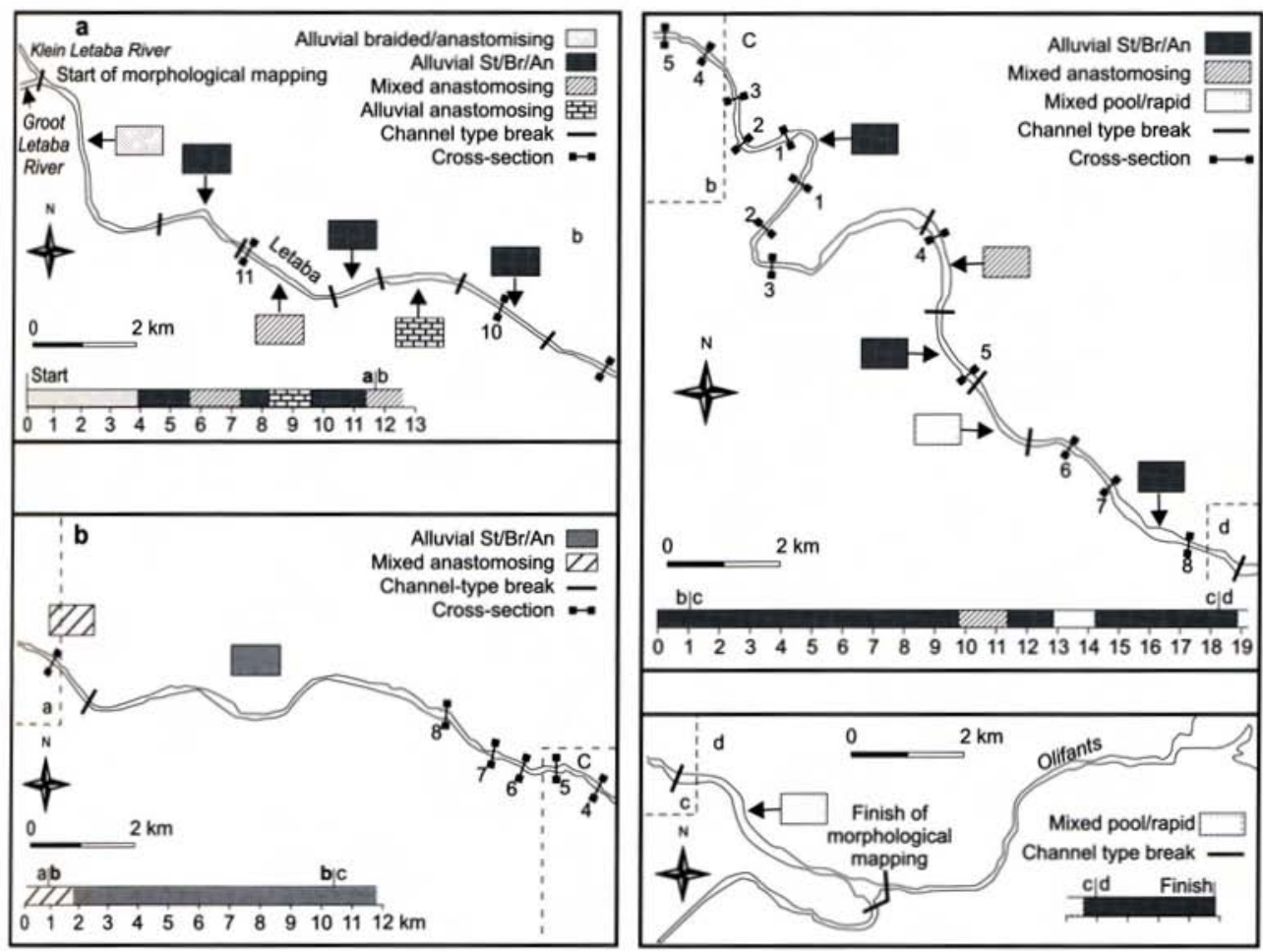

Fig. 2: The sequence of channel types along the Letaba River in the Kruger National Park (sequence a-d: upstream to downstream, west to east through the reserve to the confluence with the Olifants River).

usage is likely to outstrip water availability within the catchment, and consequently land degradation and sediment production will increase (Steffen, Robertson \& Kirsten 1990b; Birkhead et al. 1995). It is therefore likely that the already degraded Letaba River will experience further reductions in water volume and an increase in sediment input. Geomorphological and ecological changes will occur as a result, and it is for this reason that the nature of geomorphological change needs to be understood.

Sediment production in the Letaba catchment has been estimated from land use, soil type, geomorphology, vegetation and rainfall variables (Steffen Robertson \& Kirsten 1990b). Yields range from $150 \mathrm{tkm}^{2} / \mathrm{a}$ to in excess of $400 \mathrm{tkm}^{2} / \mathrm{a}$ (Fig. 1c) with the highest yields occurring in the densely populated rural areas in the west of the catchment. This material will eventually be transferred from the drainage basin into the river (Knighton 1997), affecting all reaches of the Letaba River to varying degrees. Increasing pressures on the catchment as a result of greater water abstraction and an expansion of agricultural practices are likely to result in further flow reduction and increased sediment inputs to the river (Birkhead et al. 1995).

\section{Geomorphology}

The Letaba River in the Lowveld consists of a macro-channel that is incised into the surrounding landscape by some $5-10 \mathrm{~m}$ on average and over $30 \mathrm{~m}$ in the gorge close to the confluence with the Olifants River (Heritage et al. 1997). Within the macrochannel there are one or more sub-channels that are activated as discharge rises follow- 
Table 1

Description of the morphological units found on the Letaba River in the Kurger National Park

Morphological

unit

Rapid

Riffle

Pool

Braid bar

Lateral bar

Point bar

Bedrock

core bar

Lee bar

Bedrock

backwater

Alluvial

backwater

River cliff

Apical pool

Rip channel

Boulder bed

Armoured

area

Alluvial

distributary

Bedrock

distributary

Terrace

Description

Steep bedrock sections, high velocity concentrated flow.

Accumulation of coarser sediment as a topographic high point as part of a pool riffle sequence.

Topographic low point characterised by finer sediments, as part of a pool-riffle sequence.

Accumulation of sediment in mid-channel causing the flow to diverge over a scale that approximates to the channel width.

Accumulation of sediment attached to the side of the channel, may occur sequentially downstream as alternate bars.

Accumulation of sediment on the inside of a meander bend.

Accumulation of finer sediment on top of bedrock in bedrock anastomosing areas.

Accumulation of sediment in the lee of flow obstructions.

Stationary or near stationary bodies of water in bedrock, adjacent to the active channel.

Stationary or near stationary bodies of water in alluvium, adjacent to the active channel.

Vertical or near vertical alluvial erosion face.

Deep section of channel located on the outer bend of a meander, associated with point bars.

High discharge distributary channel on the inside of point and lateral bars.

Accumulation of locally derived material exceeding $0.25 \mathrm{~m}$.

Accumulation of coarser sediments due to winnowing of finer material.

Individual active channel in an alluvial braided or anastomosing system.

Individual active channel in a bedrock anastomosing system.

Relic floodplain or valley floor deposits above the present river level.

ing rainfall events. The macro-channel extends across the width of the incised valley and is characterised by discrete sedimentary deposits forming alluvial morphological units many of which are colonised by riparian vegetation.

Although the river has incised several metres into bedrock and alluvial material to form the macro-channel, the influence of bedrock on the channel floor is considerably less than that on the Sabie River (Heritage \& Moon 2000). Sediment from the degraded catchment has accumulated within the macrochannel creating a preponderance of alluvial reaches. These, often extensive, alluvial areas are characterised by sparsely vegetated sand sheets and associated lateral terrace-like deposits of cohesive alluvium. Wet season floods inundate the sand sheets whereas the terrace features are overtopped only by less frequent flows of greater magnitude. 


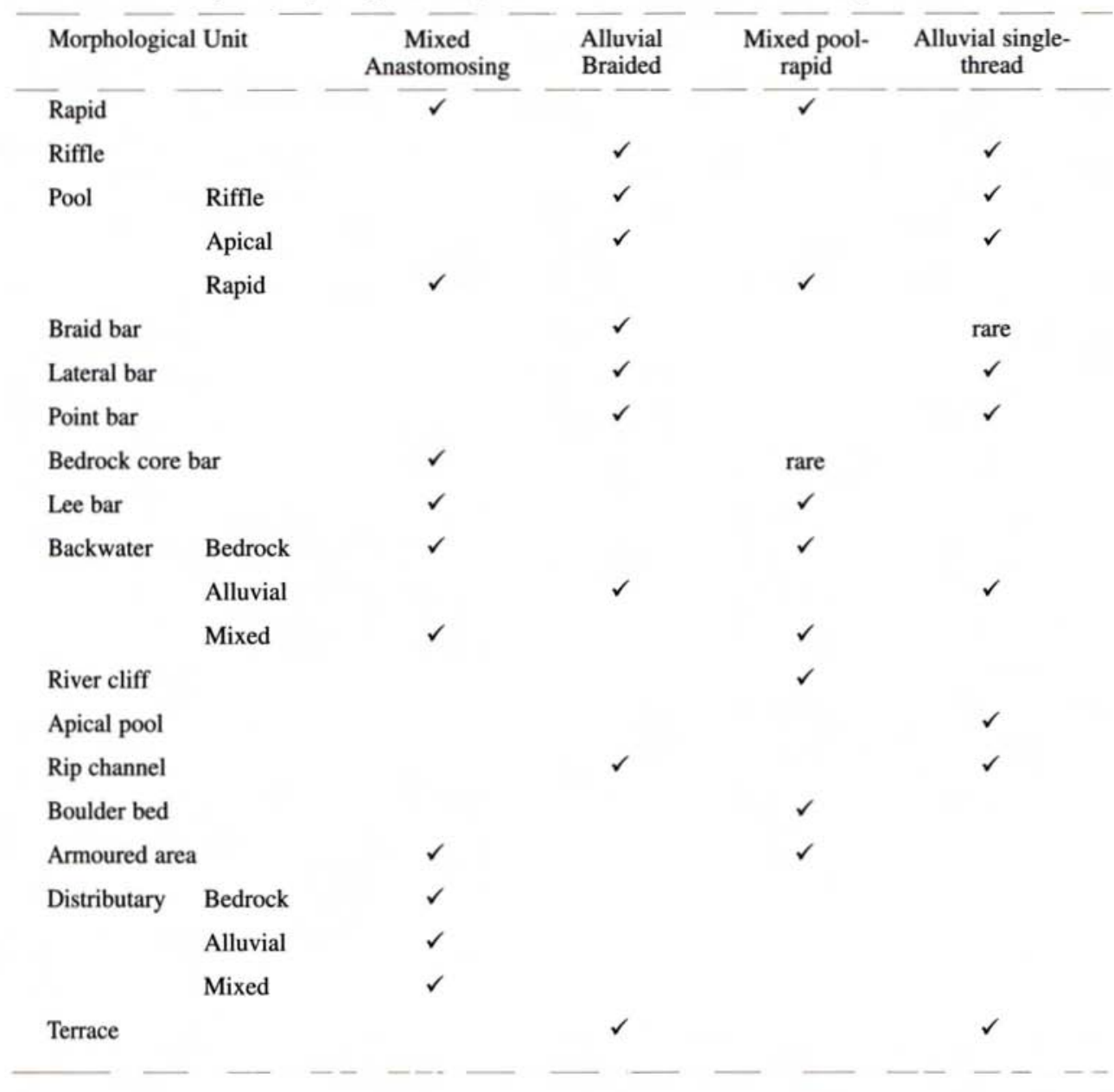

Bedrock-influenced reaches are limited in extent and exhibit considerable alluvial cover in the form of unconsolidated sands and fine gravels. In such reaches the channel divides to form a multiple distributary network flowing around bedrock outcrops exposed in the bed of the channel.

Aerial photographs taken in 1989 together with field observations were used to categorise the Letaba River in a hierarchical framework. The basic components of the framework are morphological units, each with a distinctive character and micro-habi- tat (Van Niekerk \& Heritage 1993). Morphological units are seen to associate together to form different channel types (Heritage et al. in press). There is a functional relationship between different channel types which may be grouped into reaches, where one channel type may be influencing directly the nature of the channel type upstream or downstream. The interaction of a range of flows on bedrock and alluvium has generated a varied assemblage of morphological units (Table 1). 


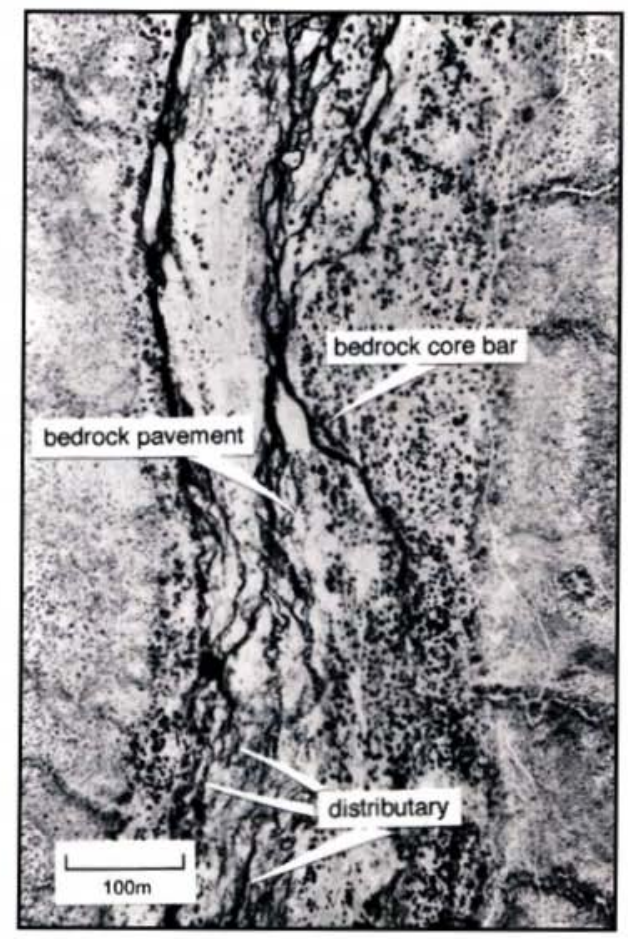

Fig. 3: A mixed anastomosing channel type on the Letaba River in the Kruger National Park.

Visual interpretation of aerial photographs (1:10 000 scale), aerial video footage taken during winter low flow conditions and extensive fieldwork provided the basis for identifying characteristic morphological assemblages or channel types. Four common channel types (mixed anastomosing, mixed pool-rapid, alluvial single thread and alluvial braided) are found along the Letaba River (Fig. 2). Gradations between the four primary channel types indicate that individual channel types are part of a spatial and temporal continuum of channel form. The channel types exhibited by the Letaba are described below.

\section{Mixed anastomosing}

Some sections of the river display a wider macro-channel than the average (Fig. 3). Both sedimentary and bedrock features (Table 2) are found in the channel which is characterised by a tortuous distributary net- work that follows weaknesses in the bedrock and covers the entire width of the macrochannel.

Water levels within the various distributary channels are often at different elevations as a result of flow being concentrated along lines of weakness as defined by the bedrock template. Locally bedrock outcrops within the channels act to obstruct the flow effectively acting as local hydraulic controls. This results in a discontinuous phreatic surface with no sub-surface water flow linkage. The alluvial deposits covering much of the bedrock exist as a thin (less than $1.5 \mathrm{~m}$ ) veneer on the interfluves between the distributary channels. The material is generally unconsolidated or only semi-consolidated being composed of sands and fine gravels with little clay or silt and there are few large bedrock core bar deposits. Occasional deposits of coarser gravels and cobbles exist as armoured areas and lag deposits in the sections of the channel dominated by bedrock. Distributary channels tend to be lined with reed and scrub vegetation. Aerial photographic analysis of the effects of high flows (which inundate the entire macrochannel) on mixed anastomosing channels has revealed that their planform is stable in that flow returns to pre-existing channels as the flood stage diminishes.

\section{Alluvial braided}

Short sections of river are characterised by extensive sand sheets (Table 2) dissected by a multi-channel network of alluvial distributaries that flow over the sandy surface. The low-flow distributary channels split and rejoin around unconsolidated mid-channel deposits over distances that approximate the distributary width (Fig. 4). Flow levels in these channels are similar, indicating a wellconnected phreatic surface across the macrochannel. Planform change is rapid and observation of the river after a flood reveals that this is often associated with new channel cutting on the falling limb of the flood hydrograph, except where reed growth has partially stabilised and restricted the lateral 


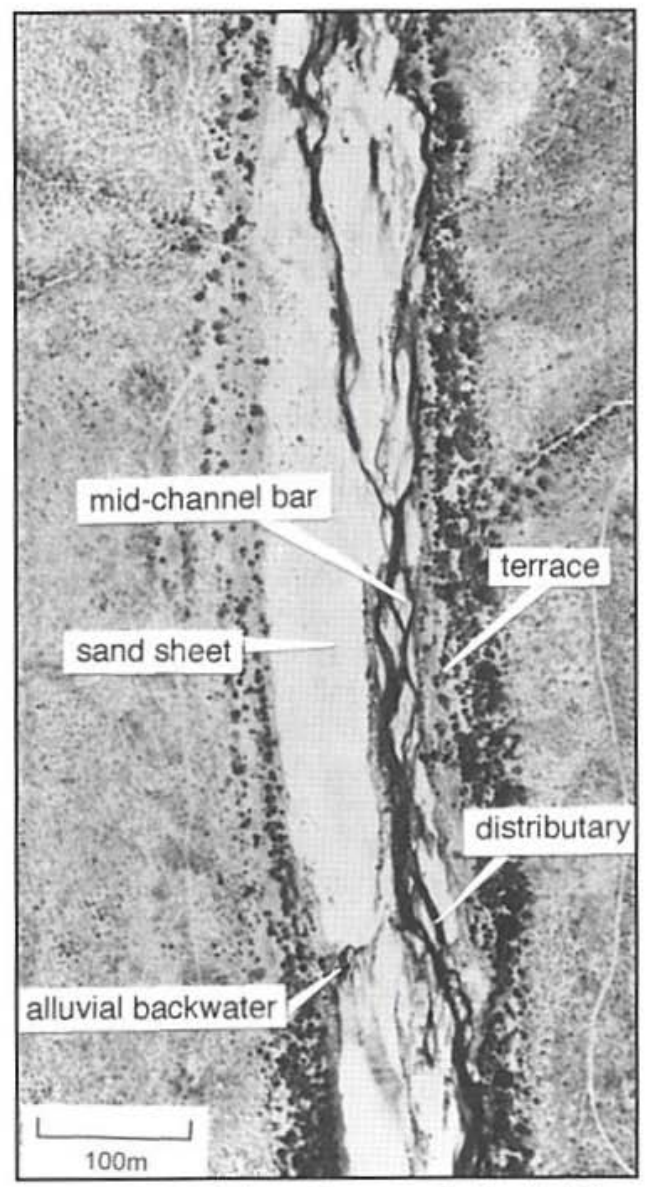

Fig. 4: A braided channel type on the Letaba River in the Kruger National Park.

migration of distributaries. Extensive sand sheets dominate the macro-channel; stalled sand dunes and seasonal distributary channels formed during the previous flood event complicate their morphology. Fine material does not accumulate on the surface of the sand sheets (Fig. 4). It is suggested that this is due to the fine material, carried by flood flows, remains in suspension because of high energy levels and continue downstream. Lower energy levels are experienced close to the macro-channel margins where fines are deposited creating sub-linear terrace-like features composed of clays, silts and sandy deposits. Occasional alluvial

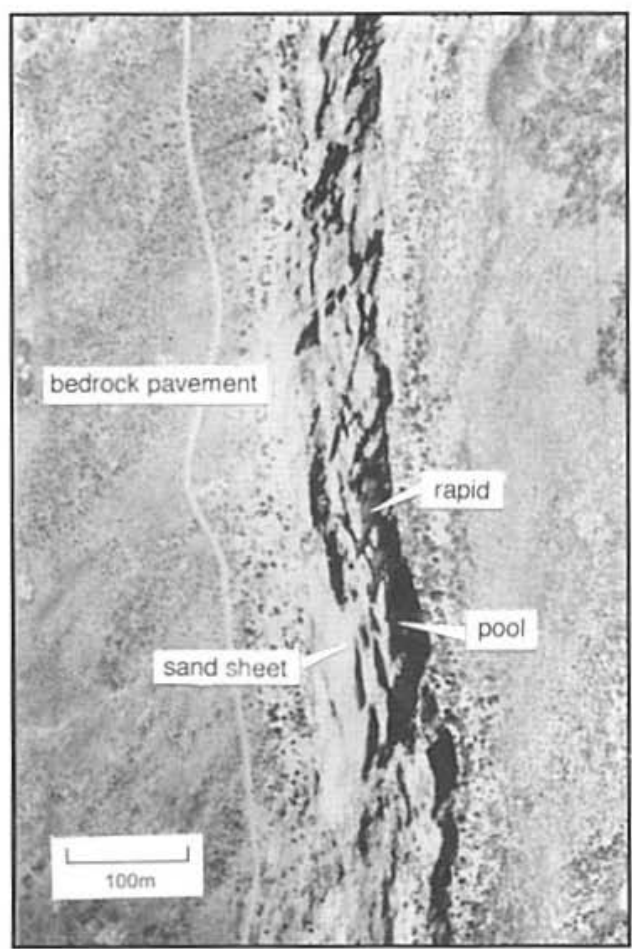

Fig. 5: A mixed pool-rapid channel type on the Letaba River in the Kruger National Park.

backwaters develop (Fig. 4) following flow recession and pool isolation. Finer material characterises the bed of these areas.

\section{Mixed pool-rapid}

Bedrock exposures on the macro-channel floor influence the course and structure of the low-flow channel and generate a series of bedrock rapids and associated upstream pools (Fig. 5). Often the flow network forms a number of sub-parallel pools separated by bedrock rapids (Fig. 5). Evidence from similar features on the Sabie River (Cheshire 1994) indicate that local geology, with alternating weaker (pools) and more resistant lithologies (rapids), influences the nature of these morphological units (Table 2). Mixed pool-rapid channels are common in the higher energy zones along the river, particularly 


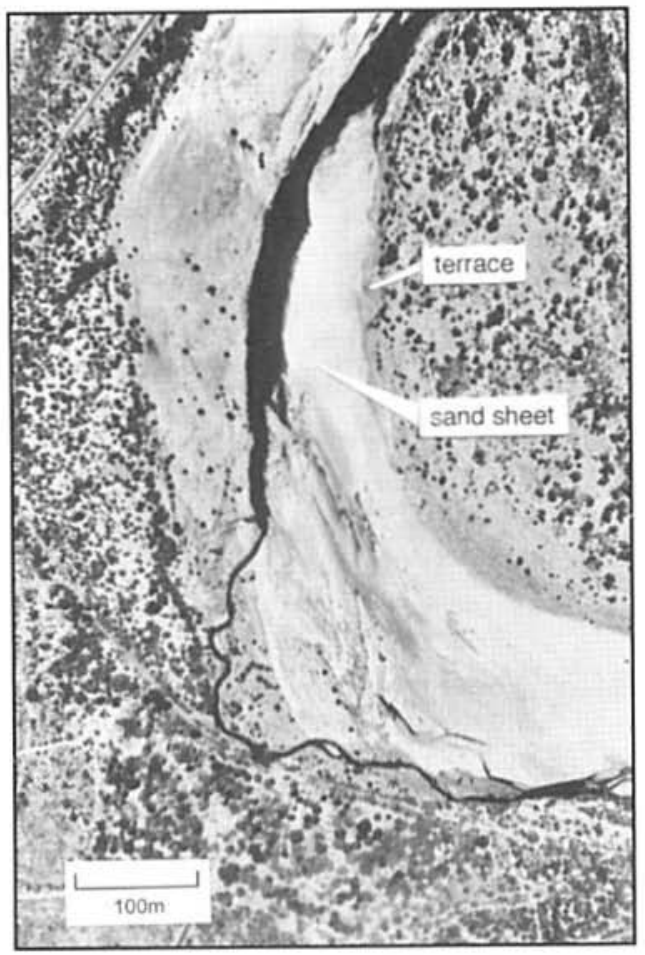

Fig. 6: An alluvial single thread channel type on the Letaba River in the Kruger National Park (wave trains can be seen in the top right of the sand sheet).

where sediment supply is locally reduced, for example downstream of small dams. Cohesive sedimentary deposits are restricted to occasional dissected remnants of more extensive terrace features often forming exposed 'river cliffs' near the sides of the macro-channel. Alluviation across much of the macro-channel forms extensive but thin sand sheets infilling lower areas of exposed bedrock pavement. Coarser armoured areas occasionally form riffle-like features of lag material in the active channel (Fig. 7a).

\section{Alluvial single thread}

There is evidence of switching between braided, mixed anastomosing and single thread systems in alluvial sections of the river. In single thread reaches low flows are conveyed along a single alluvial channel across an extensive sand sheet where no bedrock features are evident (Table 2). Often such channels are close to the side of the macro-channel, and alternate from side to side bearing no relation to the macro-channel planform (Fig. 6). There are signs of incipient braiding with the common development of shallow low flow riffles composed of sand and fine gravels and mid-channel bars (Fig. 7b). The extensive channel-side reed growth, however, restricts lateral erosion and stabilises the planform. The restriction on lateral movement is often compensated for by vertical erosion, and as a result the lowflow channel appears over-deep in relation to its width. An extensive network of seasonal channels exists on the surface of the sand sheet, similar to that found in braided sections. Their development is essentially the same in both channel types (Fig. 7b). The presence of extensive cohesive alluvial deposits as lateral macro-channel terracelike features is also related to similar features composed of finer material in braided sections, and aggrade following major flood events.

\section{Channel change on the Letaba River}

Changes to the Letaba River have been analysed using aerial photographs of the river in the Kruger National Park from the 1960 s to the 1980s (Vogt 1992). These include positional changes in single thread channels, occasional new channels being cut through existing sedimentary deposits, and occasional new in-channel lateral features which were deposited in the 1960s and 1980s. Limited dissection of large point bars occurred in 1974. In multi-thread reaches, the abandonment of distributary channels as a result of bar coalescence occurred in the 1960 s and 1980s contemporaneously with the deposition of in-channel lateral features. New channels were cut through existing sediments in the 1970s. The evidence suggests periods of deposition in the 1960s and 1980s separated by an erosional phase in the $1970 \mathrm{~s}$ (Vogt 1992). 

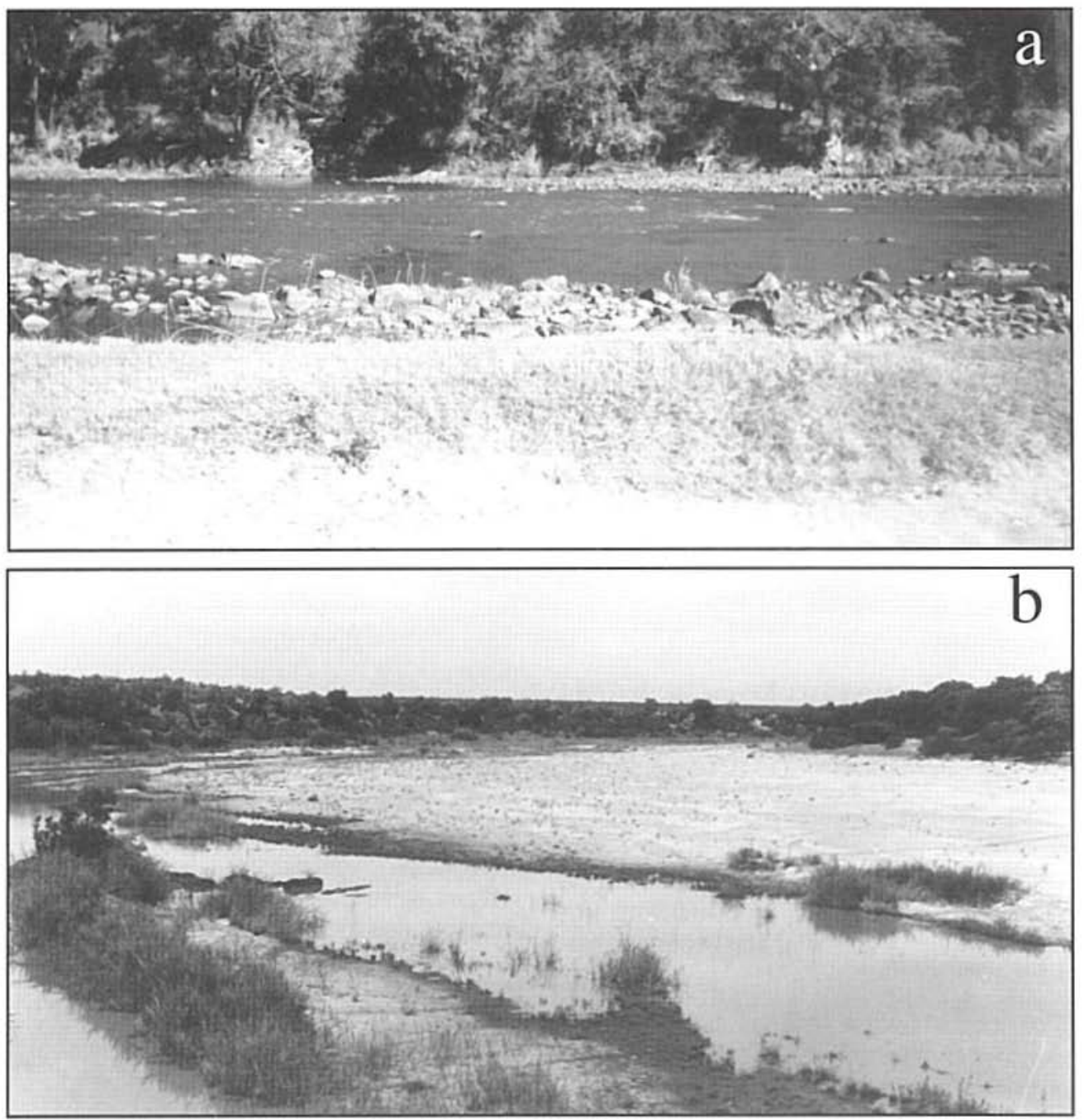

Fig. 7: (a) Armoured area in a mixed pool-rapid channel, flow is right to left and the channel width is approximately $40 \mathrm{~m}$. (b) single thread channel highlighting an extensive sand sheet, reed-covered mid-channel bar and cohesive low terrace deposits at the margins of the macro-channel, the active channel is approximately $10 \mathrm{~m}$ wide.

Evidence of short-term change has been obtained from a re-survey of twenty crosssections established on the Letaba River in 1993 (Heritage et al. 1997). The flood of February 1995, which generated a peak flow gauge reading of $655 \mathrm{~m}^{3} / \mathrm{s}$ at Engelhard Dam, close to Letaba rest camp in the Kruger National Park, resulted in remarkably little channel change. Low-flow channels remained stable. In some sections there was dissection of sand sheets as a result of channel development during the waning-flow of a flood. The significant changes were in bulk sediment mass, storage on the sand sheets with deposition and erosion occurring along the river. The pattern of change was not related to the channel type distribution (Heritage et al. 1997). This may reflect the 
movement of sediment slugs as dune field wave trains along the system (Fig. 6). Considerable deposits of fine sediment were left on terrace features on the sides of the macrochannel.

The available evidence suggests, with the exception of localised erosion and some minor channel change resulting from infrequent high-flow events, that the Letaba River is generally becoming more alluviated (Birkhead et al. 1995). With decreasing flow volumes and increasing sediment inputs the progression of change in the different channel types is likely to be from mixed poolrapid or mixed anastomosing to alluvial single thread or alluvial braided (Heritage et al.1999).

\section{Conclusion}

Despite the Letaba River having incised into bedrock in the past, alluvial channel types dominate the river. The influence of the underlying bedrock has been lost due to the deposition of unconsolidated and consolidated alluvial material. Bedrock-influenced channel types are restricted to short lengths of channel and are often associated with artificial structures that alter the sediment balance locally.

Land degradation within the catchment and associated reductions in flow reaching the downstream end of the river, have undoubtedly helped to maintain the river in its present state (Birkhead et al. 1995). Rates of channel change are slower and the magnitude of geomorphological adjustment is minor in comparison with systems such as the Sabie River (Van Niekerk \& Heritage 1993; Heritage et al. 1997; Heritage \& Moon 2000). The relative stability of the Letaba is probably related to the decline in overall flow energy consequent upon the much reduced flow frequency and magnitude as a result of intensive water abstraction within the catchment (Steffen Roberts \& Kirsten 1990a)

It is anticipated that change within the system will now occur only in relation to sig- nificant events that flood the macro-channel. The inferred consequence of such floods will be the deposition of fine sediment at the base of the macro-channel bank and the reworking of unconsolidated sands and fine gravel over the surface of extensive sand sheets. Stabilisation of some areas, particularly the banks of the low-flow distributary channels may further inhibit channel change, and the inferred consequence is the development of stable, over-deep channel networks in largescale deposits of unconsolidated alluvium.

Observation of the trends on the Letaba River suggest that development of the terrace-like cohesive deposits at the sides of the macro-channel is likely to continue by vertical accretion provided flood flows of sufficient magnitude continue to reach the Kruger National Park. Similar flows are required to maintain the sand sheets, it is inferred that these remain free of fine sediment as a result of prolonged flood recession. A reduction in the duration of intermediate waning flows may lead to the deposition of fine suspended material across the surface of the sand sheets instead of this material continuing to be transported downstream. The lack of prolonged flows capable of remobilising fine material, due to increasing water usage within the catchment, will further exacerbate the possibility of cohesive sediment build-up.

\section{Acknowledgements}

The authors gratefully acknowledge the funding provided for this project by the Water Research Commission of South Africa. Logistical support was provided by the National Parks Board of South Africa. Particular thanks must be extended to Mr Beukus Enslin and Mr Million Xhosa for their help in the field. Mr G. Dobrzynski is thanked for his cartographic skills. Anonymous referees are thanked for the many constructive comments in their reviews.

\section{References}

BIRKHEAD, A.L. \& G.L.HerITAGE. 1995. Techniques for evaluating river and reservoir sedimentation on the Sabic and Letaba river systems. Procedures of the Seventh South African National 
Hydrology Symposium (Electronic format), September 1995, Grahamstown, South Africa.

CHESHIRE, P. 1994. Geology and geomorphology of the Sabie River, Kruger National Park, and its catchment area. Centre for Water in the Environment. Internal report; no. 1/94. University of the Witwatersrand, Johannesburg.

Heritage, G. L., M. E. Charlton \& S. O'Regan (in press). Morphological classification of fluvial environments: an investigation of the continuum of channel types. Journal of Geology.

Heritage, G.L. \& B.P. Moon. 2000. The contemporary geomorphology of the Sabie River in the Kruger National Park. Koedoe 43: 39-55.

Heritage, G.L.. A.W. van Niekerk \& B.P. MoON. 1999. Classifying bedrock influenced semi-arid river systems: extending the continuum concept. Pp. 53-80, In: MILL.er, A.J. \& A. GUPTA (eds). Varieties of Fluvial Form. Chichester: Wiley

Heritage, G.L., A.W. van Niekerk, B.P. MOON, L.J. BroAdHURST, K.H. Rogers \& C.S. JAMES. 1997. The geomorphological response to changing flow regimes of the Sabie and Letaba river systems. Pretoria: Water Research Commission. (Water Research Commission report; no. $376 / 1 / 97$.)

Heritage, G. L., A. L. Birkhead, L. J. Broadhurst \& B. R. HARNET. 1999. The influence of flooding on the erodability of cohesive sediments along the Sabie River, South Africa. Sedimentology 28, 131-145.

KNIGHTON, A.D. 1997. Fluvial forms and processes: a new perspective. London: Edward Arnold.

ROWNTREE, K. M. \& R. A WADESON. 1996. Translating channel geomorphology into hydraulic habitat: application of the hydraulic biotope concept to an assessment of discharge related habitat changes. Pp. 342-351. In: LeClerRC, M., H. Capra, S. Valentin, A. Boudreault \& Y. COTE. (eds.). Ecohydraulique 2000: Proceed- ings of the second IAHR international symposium on hydraulics and habitats. Quebec. Canada: IAHR.

ROUNTREe, M. W.. K. H. Rogers \& G. L. Heritage (in press). Landscape state change in the semiarid Sabie River, Kruger National Park. in response to flood, drought and fire. South African Geographical Journal.

STEFFEN ROBERTSON \& KIRSTEN. 1990a. Water resource planning of the Letaba River basin. study of development potential and management of the water resources (Hydrology: Flow Generation). Pretoria: Department of Water Affairs. (Department of Water Affairs report: no. B800/001390)

STEFFEN ROBERTSON \& KIRSTEN. 1990b. Water resource planning of the Letaba River Basin. study of development potential and management of the water resources (Executive Summary). Pretoria: Department of Water Affairs. (Department of Water Affairs report; no. P B800/00/0190.)

Van Niekerk, A.W. \& G.L. Heritage. 1993. Geomorphology of the Sabie River: overview and classification. Johannesburg: University of the Witwatersrand. (Centre for Water in the Environment report: no, 2/93)

VoGT, 1. 1992. Short-term geomorphological changes in the Sabie and Letaba rivers in the Kruger National Park. Unpublished M.Sc. dissertation, Department of Geography and Environmental Studies, University of the Witwatersrand, Johannesburg.

WADESON. R. \& K. ROWNTREE, 1995. A hierarchical geomorphological model for classification of South African river systems. Pp. 49-68. In: UYs, M.C. (ed.). Classification of rivers and environmental health indicators. Pretoria: Water Research Commission. (Water Research Commission report: no. TT63/94.) 